\section{Teaching and Learning in Medical School}

G. E. Miller, M.D. (Editor), S. Abrahamson, PH.D., I. S. Cohen, PH.D., H. P. GRASER, M.D., R. S. Harnack, Ph.D., A. LAND, ED.D. Pp. xiii +304 . Cambridge, Massachusetts: Harvard University Press. Published for the Commonwealth Fund by Oxford University Press. 1962. 44s.

This book is about the American scene, but it is well worth study by medical educators in Great Britain who wish to learn contemporary concepts of teaching.

The authors' theme is that the only real learning is done by the student himself, and that his teachers should realize that they teach students and not subjects. This is perhaps salutary to those of us who think that expertise in our subject is enough and that the imparting of this knowledge is of secondary consideration and will naturally follow.

The book is divided into four main sections. The first section is about the medical student, his selection and the medical school. The authors point out that the objectives of a medical education are not well defined. In general we all hope to train 'a good physician', a term everyone understands but of which individual concepts differ.

It would seem that the selection of students is on an assessment of the ability to stay the medical school course; this has not yet been shown to have much relation to his subsequent career in medicine and his development into a 'good physician'. Evidently there is a schizophrenia of medical school selectors in the U.S., for it would seem that lip service is paid to the advantages of a broad liberal education in order to produce a good physician, but in selection, emphasis is laid on scientific achievement. This seems only too true when applied to Great Britain, now in the throes of a shortage of University places, and a consequent rat race for the narrow status symbols of G.C.E. 'A' or ' $\mathrm{S}$ ' levels.

The second section deals with the process of learning, and it is stressed that the student is the centrepiece, not the subject matter. An important factor in learning is motivation, and the authors deplore that the desire to become a doctor is lost sight of, particularly in the early years of medical training.

Much space is given to theories of learning, and particular mention may be made of transfer, i.e. the utilization of knowledge to face new situations. The authors are scathing about the traditional methods of transfer via mental discipline, e.g. learning Latin, pure and obtuse science, etc., as intellectual exercises for their own sake. It is this, they deplore, which has kept Universities apart from changing society outside their walls. They believe that transfer and motivation should go hand in hand, and that the more closely the curriculum resembles the professional behaviour, the more closely the student can identify himself with it, and, through participation, the greater the impact and the easier the transfer.

If this is accepted, it means that the medical curriculum must be planned as a whole right from the start, and each department must co-operate to produce the complete doctor rather than a specialist in each subject.
The third section is devoted to the tools of instruction and will be most helpful to those medical teachers whi wish to improve their teaching.

The fourth section concerns the evaluation and measurement of learning, but to the British reader this is possibly only of interest rather than of practical application, particularly on the subject of grading.

All in all, the book is of great interest, and as far as the reviewer knows, the first serious attempt to make a stuct of the technique of teaching medical students.

\section{Genetical Variation in Human Populations}

G. A. Harrison (Editor). Vol. IV of the Symposia of the Society for the Study of Human Biology. Pp. vidi + 185, illustrated. Oxford, London, New Yorg and Paris: Pergamon Press. 1961. 45s.

Most metaphysicians have been trained to regard the inductive method as the method of natural science supposing that by contemplation of a series of regh larities in nature the observer could discover the Laves which governed them. To a practising scientist nothing could seem further from the truth: granted, a scientist observes facts, but any observation may strike from ${ }^{2} \mathrm{~L}$ brain of the scientist one or more hypotheses wifot could relate what has been observed to the pre-existing body of knowledge. The scientist's task now is 젬 this is his peculiar distinction) to deduce from eact hypothesis consequences which can be tested by observation or experiment; if a hypothesis leads conclusions which can be shown to be false, then th hypothesis must be abandoned or modified; while if n falsified, more and more stringent tests must be devised

These two methods have been contrasted by Popper in his famous book " The Logic of Scientific Discovery $\rightrightarrows$ and few scientists or philosophers could hope for clearer demonstration of the "hypothetico-deductives method put forward by Popper than the observations and theories put forward in this book. Recent advance in our understanding of blood groups, abnormal hæmॄ. globins, enzymes, haptoglobins and transferrins, have been made largely as a consequence of observations. stimulated by new hypotheses; and when authors such is Allison, Barnicot, Gartler and Mourant unite to discuss the significance of balanced polymorphism in mankind, we begin to understand how we can study evolution work in our own species. The old hypothesis of genetic drift in small isolated groups is found to inadequate to account for observed differences, an natural selection is becoming more acceptable; fof example, only natural selection seems sufficient to explain why the negro populations of Curaçao an® Surinam differ so greatly in their frequency of the sickle cell trait. Harrison points out that even skin colour may be a critical factor in survival in certak ecological niches, while Mrs. Holt discusses a gene tically determined factor, dermal ridge patterns, which probably selectively almost neutral.

Everybody who is interested in the justification of the theory of evolution should study this book; it should attract not only the geneticist and anthropologist, bi also any medical or other scientist interested in evolution 